\title{
Syncretism in The Drama Script of Syekh Siti Jenar Written by Martha Vredi Kastam
}

\author{
Ulfa Tursina $^{1}$, Sahid Teguh Widodo ${ }^{2}$, and Kundharu Saddhono ${ }^{3}$ \\ \{ulfatursina@student.uns.ac.id ${ }^{1}$, sahidteguhwidodo@gmail.com², \\ kundharu_s@staff.uns.ac.id ${ }^{3}$ \} \\ ${ }^{1,2,3}$ Universitas Sebelas Maret, Surakarta, Indonesia
}

\begin{abstract}
The This study will answer many assumptions of the people that obscure the history of Syekh Siti Jenar and its religion. The formulation of the problem in this article is how the syncretism of Islam and Java in the figure of Syekh Siti Jenar and the factors that influence syncretism. The purpose of the research is to find out the factors influence of Syekh Siti Jenar in conducting syncretization. In this study, the author uses the library research as a type of research. Library research is a type of qualitative research. The subject of this study is a Syekh Siti Jenar's drama script. The results of the study show that in the teachings of the character Syekh Siti Jenar, there are elements of insolence and Javanese that can be blended with Javanese culture without much friction in terms of the deep teachings.
\end{abstract}

Keywords: syncretism, drama script, Javanese Islam, Syekh Siti Jenar

\section{INTRODUCTION}

Literature comes from Sanskrit which means writing or essay [1]. Literary work or literature is a form of artistic creation that uses a sign system (in the form of language) as a vehicle for exposure, delivery, depiction of atmosphere, and certain values. As an artistic creation, the presence of these literary works is also intended to provide certain emotive effects for the respondent. Regarding the purpose of the creation of literary works, literature aims to entertain by presenting beauty, giving color to life (misery and enjoyable) or giving a release into the world of the imagination of the reader.

Literature is a product of social phenomena and made by community of language. The aesthetic language of literary works is a means that serves as a communications tool to reveal the human life. Therefore, a work of literature in General, describes problems that include human life. Literary work serves entertaining and beneficial to readers. Entertaining literature by way of presenting, giving meaning to life (death, misery, or happiness) and became a means to convey a message about the truth, about what is good and bad[2].

One form of literature is drama's manuscript. Before writing a drama script, the author conducted research through ancient manuscripts or in old Java called pupuh from various regions. The researchers examined the history of the existence and teachings of Syekh Siti Jenar. One of the pupuh said that in the history of the spread of Islam in Java during the life of Syekh Siti Jenar, precisely in the era of the Islamic kingdom. Walisongo whose teachings dominated the kingdom of Demak directed the infidel to him because of the teachings of Syekh Siti Jenar 
considered to deviate from the teachings of the Guardians. Walisongo are several people who understand and teach Islamic teachings in Java Island.

The interesting thing that Syekh Siti Jenar is more popular among kejawen as a central figure and even by some researchers considered as one of the teachers in Java it is actually infidel and deemed heretical by Walisongo, who in his Islamic da'wah also uses elements of kejawen (Javanese approach). Based on the explanation above, the author is interested in studying the figure of Sheikh Siti Jenar and his teachings. Based on the background, the author conducted a study entitled "Syncretism in the Drama Script of Sheikh Siti Jenar Written by Martha Vredi Kastam".

\section{METHOD}

The research method used in this study is descriptive qualitative method by studying the syncretism in the Drama Script of Sheikh Siti Jenar Written by Martha Vredi Kastam. Descriptive qualitative method based on culture is a descriptive method and logical definition method that links values in culture with real life [3]. The type of research in this paper is library research. This research was conducted by collecting data from various written documents obtained from various primary sources in the form of manuscripts, books, magazines, reports, theses, dissertations and official letters. While secondary sources are used to strengthen analysis and collect data, to gather information that is relevant to the topic or problem being studied. To process this data, it is done by gathering information sources from the text and interviewing experts who know history.

\section{RESULT AND DISCUSSION}

\subsection{The Summary of Syekh Siti Jenar's Drama Script}

The relationship of literary work (literature) with society, technology, and public interest influences the development of literary theory [4]. However, as close as any literary work with its social structure, there is always an element of fiction and imagination. Drama is a portrait of joy and sorrow and also a general description of human life. This is in line with Somers' opinion, which states that drama is a reality of reality [5].

Syekh Siti Jenar's Drama script written by Vredi Kastam Marta tells that Syekh Siti Jenar has many followers from among the small and many people who have come from among the nobles. Due to the political freedoms taught, the Demak kingdom was concerned with the increasing influence of Sheikh Siti Jenar. This is seen from the attitude of the people who do not appreciate the proponents of the trustees. Therefore the Demak empire assumes that the authority of Sheikh Siti Jenar can decreasing the authority of the Sultan and the kingdom of Demak.

The accusations are widely directed at Sheikh Siti Jenar. Some of these allegations are open secret knowledge to the public, deviant teachings, to accusations of makar called mbalelo in Javanese. against the kingdom of Demak. In providing teaching on the science of tasawuf Sheikh Siti Jenar regardless of status, his knowledge is given to all people, openly and dialogically.

Syekh Siti Jenar's belief deviated from the Walisongo. The belief called Manunggaling Kawula Gusti. It disrupt the principle of Walisongo because they deviated from Islamic guidance. Walisongo assume that Syekh Siti Jenar said he was God himself. And the accusation as the reason for Syekh Siti Jenar's death sentence is that Syekh Siti Jenar teaches knowledge that is deemed heretical to people who do not have adequate sufistic abilities. 
The end of the conflict between Syekh Siti Jenar and the saints board culminated during the hearing of the saints who were in the title of Sunan Kudus in front of the Sultan of Demak, to discuss Syekh Siti Jenar. Two santri messengers were sent to invite Syekh Siti Jenar at the cot where he had been asked to be brought before the Sultan of Demak. They have arrived there, they are told that God is in the cave. They asked God to come face to face. Two santri gets answers if God is not in the cave, which is only Sheikh Siti Jenar. They ask to come both God and Sheikh Siti Jenar. This time, Sheikh Siti Jenardibwa is facing the Sultan of Demak.

In this meeting, Syekh Siti Jenar explained the final understanding that only Allah exists and there is no real difference that can be distinguished between God, humans and all other forms. Sunan Kudus justifies the discourse, but he asks that something like that not be explored because it can make ignoring sharia. Syekh Siti Jenar replied that ritual worship without content is only religious behavior of the fool. From the conversation between Siti Jenar and Sunan Kudus, the problem is the delivery to the community. According to Sunan Kudus, Syekh Siti Jenar understand that he can not yet be conveyed to the widespread society that makes them confused, especially when there are still many new converts, because Syekh Siti Jenar lived in the transition from the Hindu kingdom to the Islamic kingdom in Java.

Through the deliberation of the Guardians and the Sultan of Demak, Sunan Kudus ordered that Syekh Siti Jenar's body be burned in the middle of Demak square. When the Pati Obong was declare in the center of Demak's square was executed, Syekh Siti Jenar immediately concentrated, shutting down the breathtaking doors and shortly afterwards the breath was in the middle of the war with the release of a lightning fastener. Syekh Siti Jenar had died, but after the fire was over, the Sheikh Siti Jenar's body was lost.

\subsection{The Javanese Islamic Syncretism of Syekh Siti Jenar}

Sinkretism is a process of fusion of several religious ideas or schools. In syncretism, there is a process of combining various elements of flow or understanding, so that the results obtained are in different forms to look for harmony and balance in the form of concrete details that have the ability to generate ideas and emotions in the reader's mind, so that something that doesn't appear will be more visible[6\}. In this play, Syekh Siti Jenar.

Syncretism is a process occurs confusing various elements of flow or understanding, so that results are obtained in different abstract forms to find harmony, balance. This term can refer to efforts to join and do an analogy to some traits of tradition, especially in religious theology and mythology, and thus confirms a the unity of the underlying approach allows it to apply inclusive of other religions[7].

The discussion of Syekh Siti Jenar begins with the concept of God according to the view of Syekh Siti Jenar as a single reality and the return of everything. The heart of Syekh Siti Jenar admitted as God's essence, rational view is regarded as a starting point, a human life has twenty attributes (nature), tangible, nonsense, endless, different with new goods. Power, will, and knowledge, life, hearing, sight, power, willedness and knowledge of which twenty are collected inside. The virtue of being an absolute form is called essence, there is no end to the root, nothing its origin and purpose. Sheikh Siti Jenar who has the attributes of God[8].

In Syekh Siti Jenar's view, life in today's world is no more as a form of death. On the contrary, the deaths precisely saw him as the beginning of life more lasting. Such a view is also true many grow in the consciousness of almost every Javanese and Muslim life, though its function is not as striking as the teachings of Sheikh Siti Jenar. The view is based in the sense that this life is still approaching the soul of a new nature (new) which in the final round will be damaged and has a dirty (najis in Moslem) nature. The property is damaged and the impurities of the soul is the barrier of human union with God [16]. In different side, sense and function, 
the purity of the soul also grows deep the awareness of Javanese and generally Muslim throughout the Islamic world. This is a part of Manunggaling Kawulo Gusti from Syekh Siti Jenar

"Syekh Siti Jenar dengan Tuhan,

Tuhan dengan Syekh Siti Jenar,

Syekh Siti Jenar dan Tuhan

Tuhan dan Syekh Siti Jenar

Dibolak balik seribu kali seperti serabi." (Utusan I Halaman 6)

"Syekh Siti Jenar with God,

God with Syekh Siti Jenar,

Syekh Siti Jenar and God

God and Syekh Siti Jenar

Thrown back a thousand times like serabi."(Message I, page 6)

In the view of Syekh Siti Jenar, God is the essence of the absolute being have power, will, and knowledge, life, hearing, sight, power, will and knowledge. According to Syekh Siti Jenar who is called the soul is the voice of a conscience is an expression of the essence of God that must be obeyed and obeyed by his commands. Humans are a part of God. In point the peak of oneness is the culmination of the simplification process, in terms of this soul is gradually isolated from foreign things by itself, except against God.

\section{CONCLUSION}

Based on the results of data analysis, it can be concluded that Syekh Siti Jenar is a historical figure on Java who is famous for his beliefs about Manunggaling Kawula Gusti. It shows that existence of humans or universe as something that does not exist for a long time because there is only the essence of God. Humans and the universe belong to God. In the end, humans will return to Him (God). The drama script also explain thoughts and behaviors of Syekh Siti Jenar can be done with syncretism so that its meaning in accordance with the enclosing context can be properly captured. Syekh Siti Jenar's thinking also has a good mandate to live a life based on norms and values in society. This drama script that discusses Syekh Siti Jenar is able to provide good education for viewers about the values of life and divinity.

\section{REFERENCES}

[1]. R. M. Noor. Pendidikan Karakter Berbasis Sastra Solusi Pendidikan Moralyang Efektif. Yogyakarta: Ar-Ruzz Media. 2011.

[2]. R. Devilito, N. E. Wardani, and K. Saddhono. "Character Education Through its Depiction of Life in The Novel Entitled Kerumunan Terakhir by Okky Madasari (Psychologycal Analysis of Literature)." Lingua Didaktika: Jurnal Bahasa dan Pembelajaran Bahasa, Vol. 11, No. 2, pp. 185-194, 2017.

[3]. R. Williams. Vocabulary of culture of society . London: croom helm Ltd. 1976.

[4]. $\quad$ N. K. Ratna. Teori, Metode, dan Teknik Penelitian Sastra. Yogyakarta: Pustaka Pelajar. 2011.

[5]. Kinayati. "Pesona Karya Sastra dalam Pendidikan dan Pengajaran”. Jurnal Pendidikan dan Kebudayaan, Vol. 63, No. 12, pp. 20-26, 2006. 
[6]. J. R. Hare. Johnny Saldaña (2005), Ethnodrama: An Anthology of Reality Theatre. Forum: Qualitative Social Research, Vol. 9, No. 2, pp. 1-15, 2008.

[7]. T. Milawati. "Peningkatan Kemampuan Anak Memahami Drama dan Menulis Teks Drama melalui Model Pembelajaran Somatis Auditori Visual Intelektual (Savi)". Portal Jurnal Universitas Pendidikan Indonesia, Vol. 17, No. 2, pp. 70-78, 2011.

[8]. T. G. Purwaning, Kuswarsantyo. "Nilai Pendidikan Karakter dalam Ragam Gerak Tari Srimpi Pandelori.“ Jurnal Mudra, Vol. 33, No. 2, pp. 182 - 190, 2018.

[9]. R. Williams. Vocabulary of culture of society . London: croom helm Ltd. 1976.

[10]. M. Q. Patton. Qualitative evaluation methods. Beverly Hills, CA: Sage Publications. 1984.

[11]. P. Spradley James. Metode Etnografi. Yogyakarta: Tiara Wacana. 2007.

[12]. M. N. Huda, Sumarlam, and K. Saddhono. "Pembelajaran Menulis Cerita Rakyat dengan Bahasa Banyumas sebagai Upaya Pelestarian Kearifan Budaya Lokal."Conference on Language and Language Teaching, 2017

[13]. K. Maile, K. Uibu, J. Mikk. "Language Teaching Strategies' Impacton Third-Grade Students' ReadingOutcomes and Reading Interest." International Electronic Journal of Elementary Education, Vol. 10, No. 5, pp. 601-610, 2018.

[14]. Natale. "Use OF Communication and Technology among Educational Professionals and Families." International Journal of Humanities and Social Science, Vol. 10, No. 3, pp. 377-384, 2017.

[15]. UU Sisdiknas No. 20 tahun 2003 dan Permendiknas No. 22 tahun 2006.

[16]. K. Saddhono and S. Supeni. "The role of dutch colonialism in the political life of Mataram dynasty: A case study of the manuscript of Babad Tanah Jawi." Asian Soc. Sci. vol. 10 no. 15 pp. 1-7, 2014 